\title{
Short-term lactation and mammary metabolism responses in lactating goats to graded removal of methionine from an intravenously infused complete amino acid mixture
}

\author{
W. Liu, ${ }^{1}$ F. Xia, ${ }^{1}$ M. D. Hanigan, ${ }^{2}$ X. Y. Lin, ${ }^{1 *}$ Z. G. Yan, ${ }^{1}$ R. R. White,${ }^{2}$ Z. Y. Hu, ${ }^{1}$ Q. L. Hou, ${ }^{1}$ and Z. H. Wang ${ }^{1 *}$ \\ ${ }^{1}$ Ruminant Nutrition and Physiology Laboratory, College of Animal Science and Technology, Shandong Agricultural University, Taian 271018 , \\ P. R. China \\ ${ }^{2}$ Department of Dairy Science, Virginia Tech, Blacksburg 24061
}

\section{ABSTRACT}

To investigate the possible pathways of Met deficiency to depress milk protein synthesis, 4 lactating goats fitted with jugular vein, mammary vein, and carotid artery catheters and transonic blood flow detectors on the external pudic artery were used in a $4 \times 4$ Latin square experiment. Goats were fasted for $24 \mathrm{~h}$ followed by a 9 -h intravenous infusion of an AA mixture plus glucose. Milk yield was recorded and samples were taken in h 2 to 8 of the infusion period, and mammary biopsy was performed in the last hour. Treatments were graded removal of Met from the infused AA mixture to achieve Met content in the infusate of 100 (complete), 60,30 , or $0 \%$ of that in casein. Graded Met removal decreased yield of milk, milk protein, and lactose linearly and tended to decrease yield of milk fat linearly. Milk protein yield decreased to 82,78 , and $69 \%$ that of complete mixture infusion, respectively, when the 60,30 , and $0 \%$ Met infusate was infused. Circulating Met decreased linearly with graded Met removal. Arterial and venous Met decreased to 36 and $23 \%$ that of complete mixture infusion, respectively, when all Met was removed out of the mixture. Concomitant with the decreased circulating concentration was a similar increase in mammary Met affinity as reflected by the linearly increased mammary Met clearance rate. The increased affinity plus the linearly increased mammary blood flow totally offset the negative effect of decreased circulating Met concentration on mammary Met uptake. The overall result was similar mammary Met uptakes across treatments ranging from 285.9 to 339.5 $\mu \mathrm{mol} / \mathrm{h}$. Mammary uptakes of the other AA measured were generally not affected by treatments except for a

\footnotetext{
Received September 4, 2018.

Accepted December 20, 2018.

*Corresponding authors: zhwang@sdau.edu.cn and linxueyan@sdau .edu.cn
}

linearly decreased Thr uptake and a trend of linearly increased Glu uptake. Consistent with the behavior of an AA mainly catabolized in the liver and mainly used for protein synthesis in peripheral tissues, mammary uptake to milk output ratios of Met measured in the present study ranged from 1.25 to 1.49 and was not affected by treatments. For the other AA measured, the ratio of Thr was linearly decreased and that of Glu was linearly increased by graded Met removal. Graded Met removal linearly elevated circulating urea $\mathrm{N}$ and glucose concentrations, indicating enhanced wholebody catabolism of AA and hepatic gluconeogenesis. Treatments had no significant effects on circulating insulin, growth hormone, and the other hormones and metabolites measured. Phosphorylation status of eIF4E binding protein 1 tended to decrease linearly and that of p70S6k was linearly decreased by graded Met removal, indicating depressed signal in the intracellular mechanistic target of rapamycin complex 1 (mTORC1) signaling pathway. In conclusion, results of the present study indicated that the mTORC1 pathway and wholebody AA catabolism rather than mammary uptake appeared the drivers for changes in milk protein synthesis in response to varying Met supply.

Key words: goat, lactation, methionine, mTORC1, milk protein

\section{INTRODUCTION}

The conversion of dietary $\mathrm{N}$ into product is quite inefficient in lactating ruminants relative to that in growing pigs. Farm surveys indicated that the efficiency for growing pigs was about $40 \%$ (Nahm, 2002) and that for lactating cows was about 25\% (Hristov et al., 2004). Though one can argue that $\mathrm{N}$ digestibility is lower in ruminants than that in monogastric animals due to dietary roughage, this only explains part of the difference. Nitrogen digestibility in growing pigs is about 20 points higher than that in lactating cows ( $\sim 85$ vs. $65 \%$; Baker, 1996; Lapierre et al., 2005), which explains about half 
of the difference in dietary $\mathrm{N}$ conversion efficiency. Postabsorptive $\mathrm{N}$ efficiency in lactating ruminants is also lower than that of growing pigs. Although the conversion efficiency of MP in growing pigs fed diets with well-balanced AA could reach 87\% (Baker, 1996), it appears to be about $40 \%$ in lactating cows (Hanigan et al., 1998b; NRC, 2001; Lapierre et al., 2007). Considering the limitations in increasing dietary $\mathrm{N}$ digestibility in lactating cows, improving postabsorptive $\mathrm{N}$ efficiency without sacrificing milk yield is therefore a major strategy to increase overall dietary $\mathrm{N}$ efficiency.

The concept of efficiency implies inevitable losses of substrates during a process. With respect to the incorporation of AA into protein, the process per se results in no loss of AA. The increased loss of AA must occur elsewhere, such as the liver, portal-drained viscera, peripheral tissues, and metabolic pathways other than only milk protein synthesis in the mammary glands (Berthiaume et al., 2002; Lapierre et al., 2005). Decades of research efforts have enabled us to sketch out a general but far from detailed picture of postabsorptive AA metabolism in lactating ruminants (see review by Lapierre et al., 2005). Losses of total AA during absorption are proportional to MP supply (Hanigan et al., 2004; Lapierre et al., 2005) but there is variation in gut-associated losses among individual AA (Berthiaume et al., 2001). Except for the branched-chain AA, the liver is responsible for removing excess AA to avoid toxicity while allowing passage of AA needed to support anabolism in peripheral tissues. Net portal absorption only contributes 5 to $20 \%$ of the total individual AA inflow into the liver of dairy cows with the remainder coming from arterial supply. With each pass of arterial blood, only a small proportion of AA is removed by the liver (1 to 9\%), ensuring access to absorbed AA by the peripheral tissues. Amino acids not used by the peripheral tissues are recycled to the splanchnic bed, and the repeated cycling through the splanchnic tissues results in removal of the excess (Lapierre et al., 2005). This is demonstrated in the experiments of Wray-Cahen et al. (1997), Berthiaume et al. (2002), and Hanigan et al. (2004), where either intestinal, arterial, or jugular AA infusions resulted in a dramatic increase in hepatic removal of AA.

Contrary to the splanchnic bed, the affinity of the mammary glands for EAA is relatively high (Arriola Apelo et al., 2014), resulting in 25 to $65 \%$ or more of AA removed in each pass, thus reducing recycling to the splanchnic tissues. It has been demonstrated that the clearance by mammary is variable and driven by mammary demand, primarily for milk protein synthesis (Hanigan et al., 2000; Mackle et al., 2000; Bequette et al., 2001). Thus, increased demand within the mam- mary can stimulate affinity and uptake, but increased external supply is at least partially resisted through decreased mammary affinity (Ying et al., 2013) and uptake can be mostly maintained in the face of decreased supply through increased affinity (Guo et al., 2017). These concepts are all captured in the model of Hanigan et al. (2000), which provided greater prediction accuracy and precision than a model with static uptake kinetics.

Based on these concepts, it should be possible to decrease postabsorptive AA losses through nutritional regulation by stimulating use in mammary for milk protein synthesis while reducing the excess supply of each AA. Mechanistic target of rapamycin complex 1 (mTORC1) is at the center of intracellular signaling pathway to regulate protein synthesis (Kim et al., 2013). Its activity in mammary epithelial cells is stimulated by increased glucose and acetate supply through the AMPK pathway (Appuhamy, 2010), by elevated circulating insulin through the AKT pathway (Appuhamy et al., 2011), and by the direct actions of several EAA including Leu, Ile, Met, and Thr (Arriola Apelo et al., 2014; Liu et al., 2017), respectively. Some individual AA, such as Phe (Güttler et al., 1978) and Met (Stone et al., 2014), have been reported to be insulinotropic. Methionine is primarily catabolized in the liver, and its net splanchnic outflow is similar to that of milk protein output (Lapierre et al., 2005). Thus, it may be possible to elevate postabsorptive efficiency of AA for milk protein synthesis by modulating their circulating profile.

The objective of this work was to evaluate the relative importance of the various pathways associated with Met catabolism and use for milk protein synthesis when animals were subjected to varying Met supply whereas that of the other AA was held constant in a 9-h infusion experiment. The hypothesis was that mTORC1 pathway and catabolism of AA contributed to short-term changes in milk protein synthesis in response to varying Met supply.

\section{MATERIALS AND METHODS}

\section{Animals and Diet}

Four multiparous Laoshan dairy goats averaging (mean $\pm \mathrm{SD}$ ) $108 \pm 12 \mathrm{DIM}$ and $38 \pm 6 \mathrm{~kg}$ of BW were used. All animal handling and surgical procedures were approved by the Institutional Animal Care and Use Committee of Shandong Agricultural University. The right carotid artery was elevated to a subcutaneous position, and a blood flow detector was surgically fitted to the right external pudic artery as previously described (Guo et al., 2017). Goats were housed in individual 
Table 1. Ingredients, nutrients, and EAA compositions of the pelleted diet

\begin{tabular}{|c|c|}
\hline Item & Value \\
\hline \multicolumn{2}{|l|}{ Ingredient, $\%$ of DM } \\
\hline Corn & 14.42 \\
\hline Soybean meal & 13.61 \\
\hline Wheat bran & 4.86 \\
\hline Alfalfa hay & 33.78 \\
\hline Leymus chinensis & 28.85 \\
\hline Calcium carbonate & 0.19 \\
\hline Calcium bicarbonate & 3.73 \\
\hline Salt & 0.38 \\
\hline Premix $^{1}$ & 0.18 \\
\hline \multicolumn{2}{|l|}{ Nutrient } \\
\hline $\mathrm{ME},{ }^{2} \mathrm{MJ} / \mathrm{kg}$ of DM & 10.86 \\
\hline $\mathrm{MP}^{2} \mathrm{~g} / \mathrm{kg}$ of $\mathrm{DM}$ & 103 \\
\hline $\mathrm{CP}^{3} \%$ of DM & 16.41 \\
\hline $\mathrm{NDF}, 3 \%$ of DM & 30.84 \\
\hline $\mathrm{ADF}^{3} \%$ of $\mathrm{DM}$ & 18.89 \\
\hline \multicolumn{2}{|c|}{ EAA, ${ }^{4} \mathrm{~g} / \mathrm{kg}$ of DM unless noted otherwise } \\
\hline Lys & 10.31 \\
\hline Met & 2.69 \\
\hline His & 4.32 \\
\hline Arg & 10.88 \\
\hline Thr & 7.02 \\
\hline Val & 9.04 \\
\hline Ile & 10.85 \\
\hline Leu & 11.48 \\
\hline Phe & 9.59 \\
\hline Trp & 0.61 \\
\hline Lys, \% of MP & 10.0 \\
\hline Met, $\%$ of MP & 2.6 \\
\hline
\end{tabular}

${ }^{1}$ Premix contained (per $\mathrm{kg}$ of DM): $100 \mathrm{kIU}$ of vitamin A, $250 \mathrm{kIU}$ of vitamin $\mathrm{D}_{3}, 2,400 \mathrm{mg}$ of vitamin $\mathrm{E}, 2,000 \mathrm{mg}$ of nicotinic acid, 2,000 $\mathrm{mg}$ of $\mathrm{Fe}, 3,000 \mathrm{mg}$ of $\mathrm{Mn}, 3,000 \mathrm{mg}$ of $\mathrm{Cu}, 14,000 \mathrm{mg}$ of $\mathrm{Zn}, 100 \mathrm{mg}$ of Se, $180 \mathrm{mg}$ of I, and $40 \mathrm{mg}$ of Co.

${ }^{2}$ Data were calculated according to NRC models (NRC, 2001) based on contents of EAA and RUP of the ingredients measured in our laboratory.

${ }^{3}$ Laboratory-determined data.

${ }^{4}$ Calculated data from a laboratory-determined data set of AA composition of feed ingredients.

stalls before and after each experimental period, and in individual metabolism stalls during each period. The goats were fed and milked twice daily at 0800 and 1800 $\mathrm{h}$ except as noted below during the infusion.

The pelleted diet that was fed was predicted to provide $10.86 \mathrm{MJ}$ of $\mathrm{ME}$ and $49.44 \mathrm{~g}$ of $\mathrm{MP} / \mathrm{kg}$ of $\mathrm{DM}$ according to AFRC (1993, Table 1). The daily amount of the diet offered was adjusted to maintain a $5 \%$ refusal rate. Goats were allowed free access to water throughout the experiment.

\section{Experimental Design and Procedure}

The experimental design was a $4 \times 4$ Latin square with four 15-d periods. The complete AA mixture that was used was formulated according to the profile of casein (Table 2). Treatments were graded removal of Met from the complete mixture. This was achieved by substitution of Met with glutamate on a molar basis. The final Met content in the 4 infusates were 100 (complete), 60, 30, and $0 \%$ of that of in the complete mixture. Infusates were prepared and infusion was performed according to the procedures described previously (Guo et al., 2017).

Two days before each experimental period, indwelling catheters were placed in the left jugular vein, right carotid artery, and right mammary vein of each goat. Goats were fasted for $35 \mathrm{~h}$ with infusions of AA and glucose during the final $9 \mathrm{~h}$. Amounts of total AA infused during the $9 \mathrm{~h}$, which ranged from 37 to $58 \mathrm{~g}$, were calculated to match the MP requirement of each goat according to AFRC (1993) based on their respective milk protein yield recorded for the successive $3 \mathrm{~d}$ before the infusion. The amount of glucose infused was calculated to provide $3.6 \mathrm{mg}$ of glucose $/ \mathrm{kg}$ of BW per min according Guo et al. (2017). Feeding was restored after completion of each infusion. Goats were moved into individual stalls and rested for $10 \mathrm{~d}$ between each experimental period.

\section{Sampling and Analysis}

Goats were milked at 1 and $8 \mathrm{~h}$ after the start of the infusion. Milk collected at the second milking (milk secreted during the 7-h interval) was collected, weighed, recorded, and sampled for later analysis. Before each milking, 1 IU of oxytocin was intravenously injected into each goat to allow for complete milk removal (Be-

Table 2. AA profile of the complete AA mixture ${ }^{1}$

\begin{tabular}{ll}
\hline Item, g/100 g of total AA & Value \\
\hline EAA & \\
Lys & 7.49 \\
Met & 2.82 \\
Leu & 8.89 \\
Ile & 4.61 \\
Val & 6.24 \\
Thr & 3.86 \\
Phe & 4.75 \\
His & 2.82 \\
Arg & 3.57 \\
Trp & 1.49 \\
NEAA & \\
Ala & 2.82 \\
Gly & 1.78 \\
Glu & 9.95 \\
Gln & 9.80 \\
Asn & 3.40 \\
Asp & 6.83 \\
Ser & 5.05 \\
Pro & 8.32 \\
Cys & 0.59 \\
Tyr & 4.90 \\
\hline
\end{tabular}

${ }^{1}$ Adapted from Bequette et al. (1996). 
quette et al., 1996). Milk samples were divided into 2 subsamples: one for AA determination after hydrolysis using an AA analyzer (Type 835-50, Hitachi, Tokyo, Japan), and the other for milk composition analysis using an infrared milk composition analyzer (Type 78110, Foss, Hillerød, Denmark). Milk samples were stored at $-20^{\circ} \mathrm{C}$ with hydrogen peroxide for later analysis. The samples for AA analysis were sent to be hydrolyzed with hydrochloric acid at a final concentration of $4 M$. The hydrolysate was filtrated through $0.2-\mu \mathrm{m}$ film before being loaded into the AA analyzer.

Five milliliters of blood was simultaneously collected from the carotid artery and mammary vein into heparinized evacuated tubes at hourly intervals from 1 to $8 \mathrm{~h}$ after the start of the infusion. Animals were kept in a standing position during blood sampling. The 7 samples taken from each blood vessel were pooled and stored at $-20^{\circ} \mathrm{C}$ for later analysis of free AA concentrations using an AA analyzer (Type 835-50, Hitachi). Blood sample was deproteinized by mixing with equal amounts of $10 \%$ sulfosalicylic acid, kept at $4^{\circ} \mathrm{C}$ overnight, and centrifuged at $15,000 \times g$ for $20 \mathrm{~min}$ at $4^{\circ} \mathrm{C}$. The supernatant withdrawn was passed through a $0.2-\mu \mathrm{m}$ film before being loaded into the AA analyzer. Plasma was prepared from an aliquot of each blood sample taken from the mammary vein and used for later analysis of metabolites and hormones. Plasma urea $\mathrm{N}$ and glucose were determined by an automatic biochemical analyzer (Type 7020, Hitachi), total protein and nitric oxide (NO) were determined by commercially available kits (Nanjing Jiancheng Bioengineering Institute, Nanjing, China), and IGF-I, insulin, glucagon, and growth hormone $(\mathbf{G H})$ were determined by RIA using commercial assay kits (Tianjin Jiuding Biochemical Engineering Co. Ltd., Tianjin, China). Mammary blood flow during each infusion period was measured using a transit time ultrasonic flow system (Type MC6PSS-LS-WCS10-GC, Transonic Systems Inc., Ithaca, NY) calibrated according to the manufacturer's instructions.

Biopsies were taken from the upper portion of the left mammary gland following the second milking (between 8 and $9 \mathrm{~h}$ of the infusion) during each period. Mammary biopsies were performed using a 12-gauge, 16-cm MG1522 Bard Magnum reusable core biopsy instrument (Bard Medical Division, 8195 Industrial Boulevard, Covington, GA). About $0.1 \mathrm{~g}$ of mammary tissue was sampled after subcutaneous injection of lidocaine hydrochloride and skin incision at the sampling position. Mammary tissue was immediately rinsed in ice-cold saline, frozen, and stored in liquid $\mathrm{N}$ for later analysis of phosphorylation of p70S6k, eIF4E binding protein 1 (4EBP1), and eIF2 $\alpha$ by Western blotting.

\section{Calculation and Statistics}

Mammary clearance rates $\left(\mathrm{K}_{\text {Clearance }}\right.$; Hanigan et al., 1998a) were calculated to assess tissue affinity for blood metabolites:

$$
\mathrm{K}_{\text {Clearance }}, \mathrm{L} / \text { time }=[(\mathrm{CA}-\mathrm{CV}) / \mathrm{CV}] \times \mathrm{BF}_{\mathrm{Mam}},
$$

where $\mathrm{CA}=$ arterial concentration of the measured $\mathrm{AA}, \mathrm{CV}=$ venous concentration of the measured AA, and $\mathrm{BF}_{\mathrm{Mam}}=$ mammary blood flow. Mammary uptake $\left(\mathrm{U}_{\mathrm{Mam}} ; \mu \mathrm{mol} / \mathrm{h}\right)$ of individual AA was calculated as

$$
\mathrm{U}_{\mathrm{Mam}}=(\mathrm{CA}-\mathrm{CV}) \times \mathrm{BF}_{\mathrm{Mam}} \times 2 .
$$

The flux was multiplied by 2 to express on a wholetissue basis. Mammary uptake to milk output ratios ( $\mathbf{U}: \mathbf{O})$ for individual AA were calculated as mammary uptake of the AA divided by the amount secreted in milk during the $7 \mathrm{~h}$ between milkings.

Data were subjected to mixed-effect regression analysis by SAS 9.0 (SAS Institute Inc., Cary, NC). The statistical model used was

$$
\mathrm{Y}_{\mathrm{ijk}}=\mu+\alpha_{\mathrm{i}}+\beta_{\mathrm{j}}+\gamma_{\mathrm{k}}+\mathrm{e}_{\mathrm{ijk}},
$$

where $Y_{\mathrm{ijk}}=$ the observed value, $\mu=$ the overall mean, $\alpha_{i}=$ the class effect of ith experimental period, $\beta_{\mathrm{j}}=$ the continuous effect of Met dose, $\gamma_{\mathrm{k}}=$ the random effect of the kth animal, and $\mathrm{e}_{\mathrm{ijk}}=$ the random error. Both linear and quadratic effects of Met dose were tested initially. When quadratic effects were nonsignificant, they were removed from the model. Significance was declared at $P$ $\leq 0.05$, and a tendency was declared at $P \leq 0.1$.

\section{RESULTS}

\section{Milk Yields and Composition}

Removal of Met from the infused mixture decreased the yields of milk, milk protein, and lactose linearly $(P$ $<0.01$, Table 3). A tendency was observed for milk fat yield and milk protein content to decrease linearly with graded removal of Met $(P<0.1)$. Milk fat to protein ratio was linearly increased by graded Met removal $(P$ $<0.05)$.

\section{Arterial Free AA}

Methionine removal decreased arterial Met concentration linearly $(P<0.01$, Table 4$)$. Removing all Met from the infusate decreased arterial Met to about one-third that of full mixture infusion. Arterial con- 
Table 3. Effects of graded removal of Met from the AA mixture infused into jugular vein on lactation performance of lactating goats

\begin{tabular}{|c|c|c|c|c|c|c|c|}
\hline Item & \multicolumn{4}{|c|}{ Met concentration in the infusate } & $\mathrm{SE}$ & \multicolumn{2}{|c|}{$P$-value } \\
\hline Milk yield, $\mathrm{g} / 7 \mathrm{~h}$ & 405.0 & 364.5 & 340.3 & 321.0 & 79.4 & 0.0003 & 0.568 \\
\hline $\mathrm{g} / 7 \mathrm{~h}$ & 17.36 & 14.29 & 13.58 & 11.99 & 1.85 & $<0.0001$ & 0.325 \\
\hline Milk fat, \% & 5.16 & 5.25 & 5.63 & 5.95 & 0.70 & 0.147 & 0.688 \\
\hline $\mathrm{g} / 7 \mathrm{~h}$ & 20.60 & 19.01 & 18.57 & 17.29 & 3.55 & 0.062 & 0.979 \\
\hline MUN & 38.72 & 34.54 & 38.86 & 36.81 & 2.41 & 0.794 & 0.498 \\
\hline
\end{tabular}

centrations of the other measured AA were generally unaffected by treatments except for that of His, Ser, and Gly. Arterial His tended to increase linearly; Gly tended to increase quadratically $(P<0.1)$; and Ser declined linearly and quadratically $(P<0.05)$.

\section{Venous Free AA}

Graded Met removal decreased venous Met linearly $(P<0.01$, Table 5$)$, and a tendency for a quadratic effect $(P<0.1)$ was observed. Removing all Met from the infusate decreased venous Met to less than onequarter that of full mixture infusion. Out of the other AA measured, graded Met removal increased venous His and Ala linearly, increased venous Ser linearly and quadratically $(P<0.05)$, tended to increase venous Thr and Cys linearly, tended to increase venous Phe quadratically, and tended to decrease venous Lys quadrati- cally $(P \leq 0.10)$. Treatments had no significant effects on venous concentrations of the other AA measured.

\section{Venous Metabolites, Hormones, and Mammary Blood Flow}

Graded Met removal increased venous urea $\mathrm{N}$ and glucose and $\mathrm{BF}_{\text {Mam }}$ linearly $(P<0.05$, Table 6$)$. Treatments tended to affect venous $\mathrm{GH}$ and $\mathrm{NO}$ quadratically in that venous $\mathrm{GH}$ varied in a down-up and $\mathrm{NO}$ varied in an up-down manner, respectively, with graded Met removal $(P<0.1)$.

\section{Mammary AA Clearance Rates}

Graded Met removal increased mammary clearance rates of circulating Met linearly $(P<0.01$, Table 7$)$. Relative to that of the full mixture infusion, the 30 and

Table 4. Effects of graded removal of Met from the AA mixture infused into the jugular vein on AA concentrations in the plasma of carotid artery of lactating goats

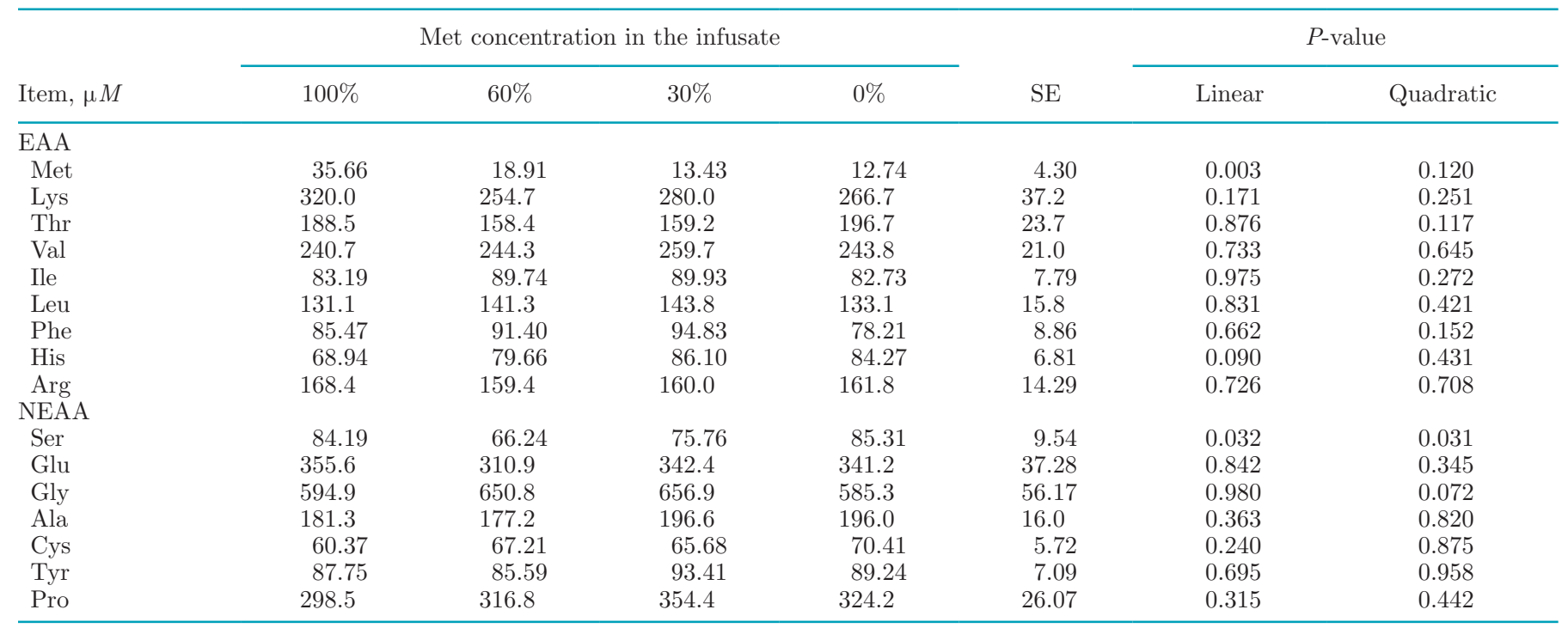


Table 5 Effects of graded removal of Met from the AA mixture infused into jugular vein on AA concentrations in the plasma of mammary vein in lactating goats, $\mu M$

\begin{tabular}{|c|c|c|c|c|c|c|c|}
\hline Item & \multicolumn{4}{|c|}{ Met Concentration in the infusate } & $\mathrm{SE}$ & \multicolumn{2}{|c|}{$P$-value } \\
\hline Met & 26.80 & 11.43 & 6.95 & 6.21 & 3.02 & 0.0008 & 0.051 \\
\hline Lys & 271.4 & 210.3 & 241.7 & 241.4 & 34.4 & 0.432 & 0.100 \\
\hline Thr & 140.1 & 126.6 & 146.5 & 192.4 & 22.3 & 0.095 & 0.102 \\
\hline Val & 192.3 & 203.8 & 239.7 & 212.8 & 20.7 & 0.233 & 0.399 \\
\hline Phe & 66.47 & 77.43 & 85.88 & 70.88 & 8.27 & 0.419 & 0.055 \\
\hline His & 59.60 & 65.70 & 79.39 & 78.10 & 7.73 & 0.031 & 0.743 \\
\hline Arg & 127.4 & 125.1 & 142.5 & 142.9 & 9.21 & 0.141 & 0.745 \\
\hline \multicolumn{8}{|c|}{ NEAA } \\
\hline Ser & 70.00 & 60.12 & 67.98 & 79.10 & 11.92 & 0.024 & 0.040 \\
\hline Glu & 309.8 & 257.6 & 294.7 & 291.9 & 39.7 & 0.818 & 0.342 \\
\hline Gly & 488.7 & 538.5 & 597.5 & 549.2 & 54.2 & 0.141 & 0.236 \\
\hline
\end{tabular}

0\% Met infusions increased mammary Met clearance rates by approximately 5-fold. Mammary clearance rates of the other AA were not statistically affected by treatments except for a trend for decreased Gly removal $(P<0.1)$.

\section{Mammary Uptakes of Circulating AA}

Graded Met removal did not change mammary uptake of circulating Met even though all the Met was removed out of the infusate $(P>0.1$, Table 8$)$. Graded Met removal decreased mammary uptake of circulating Thr linearly $(P<0.05)$ and tended to increase the uptake of circulating Glu linearly $(P<0.1)$. Mammary uptakes of the other AA measured were not statistically affected by treatments.

\section{Mammary Uptake to Output Ratio of AA}

Mammary uptake to milk protein output ratios for Met ranged from 1.24 to 1.49 and were not affected by treatment $(P>0.1$, Table 9$)$. The U:O of Thr was linearly decreased and that of Glu was linearly increased by graded removal of Met from the infused AA mixture $(P \leq 0.05)$. The $\mathrm{U}: \mathrm{O}$ of $\mathrm{Thr}$ decreased to 0.32 in the treatment with all Met removed, which implied the amount of Thr extracted in the form of free AA into mammary glands was less the amount secreted into

Table 6. Effects of graded removal of Met from the AA mixture infused into jugular vein on mammary blood flow $\left(\mathrm{BF}_{\mathrm{Mam}}\right)$ and concentrations of metabolites and hormones in the plasma of mammary vein in lactating goats

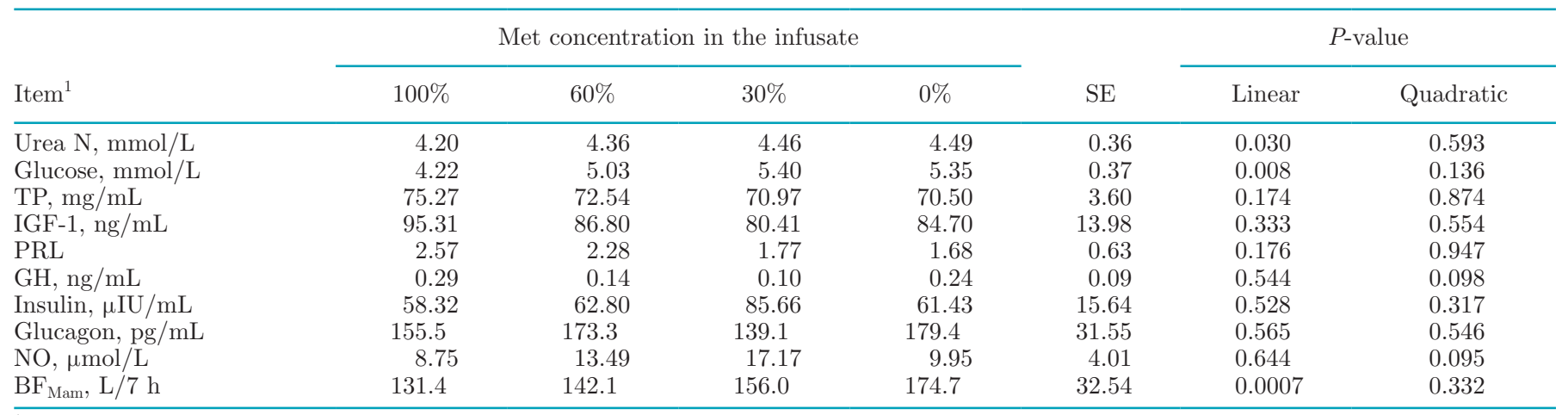

\footnotetext{
${ }^{1} \mathrm{TP}=$ total protein; $\mathrm{PRL}=$ prolactin; $\mathrm{GH}=$ growth hormone
} 
Table 7. Effects of graded removal of Met from the AA mixture infused into a jugular vein on mammary AA clearance rates (L/h) in lactating goats

\begin{tabular}{|c|c|c|c|c|c|c|c|}
\hline \multirow[b]{2}{*}{ Item } & \multicolumn{4}{|c|}{ Met concentration in the infusate } & \multirow[b]{2}{*}{$\mathrm{SE}$} & \multicolumn{2}{|c|}{$P$-value } \\
\hline & $100 \%$ & $60 \%$ & $30 \%$ & $0 \%$ & & Linear & Quadratic \\
\hline \multicolumn{8}{|l|}{ EAA } \\
\hline Met & 5.86 & 14.72 & 28.64 & 27.10 & 5.62 & 0.002 & 0.389 \\
\hline Lys & 2.78 & 4.23 & 3.25 & 2.98 & 0.95 & 0.994 & 0.342 \\
\hline Thr & 5.03 & 6.63 & 2.25 & 1.02 & 2.03 & 0.108 & 0.374 \\
\hline Val & 4.22 & 3.57 & 1.87 & 4.05 & 1.14 & 0.645 & 0.303 \\
\hline Phe & 5.25 & 3.14 & 2.63 & 3.23 & 1.66 & 0.294 & 0.400 \\
\hline His & 2.33 & 3.51 & 2.02 & 2.70 & 1.08 & 0.970 & 0.715 \\
\hline Arg & 4.81 & 4.82 & 3.12 & 4.42 & 1.31 & 0.472 & 0.598 \\
\hline \multicolumn{8}{|c|}{ NEAA } \\
\hline Ser & 3.22 & 2.53 & 2.85 & 2.89 & 1.52 & 0.881 & 0.771 \\
\hline Glu & 2.29 & 3.55 & 3.83 & 4.72 & 1.22 & 0.151 & 0.939 \\
\hline Gly & 4.46 & 3.72 & 1.84 & 1.71 & 1.24 & 0.081 & 0.943 \\
\hline
\end{tabular}

milk protein and the imbalance might be made up by other forms of Thr extracted, such as peptide-bound Thr. Treatments had no significant effects on the U:O of the other measured AA.

\section{Phosphorylation of Downstream Proteins in mTORC1 Pathway}

Graded removal of Met from the intravenously infused AA mixture tended to decrease phosphorylation status of $4 \mathrm{EBP} 1(P=0.053)$ and decreased that of p70S6K linearly $(P<0.05)$. Treatments had no significant effect on the phosphorylation of eIF2.

\section{DISCUSSION}

\section{Milk Yield and Composition}

Methionine and Lys are the 2 EAA that are frequently identified as limiting in the diets of lactating ruminants. It has been observed that increased postruminal supply of Met alone (Guinard and Rulquin, 1995; Noftsger and St-Pierre, 2003; Chen et al., 2011; Zhou et al., 2016) or in combination with Lys (Rogers et al., 1987; Donkin et al., 1989; Misciattelli et al., 2003; Appuhamy et al., 2011; Lee et al., 2012) promoted milk protein production. NRC (2001) recommended that

Table 8. Effects of graded removal of Met from the AA mixture infused into jugular vein on mammary AA uptakes in lactating goats, $\mu$ mol/h

\begin{tabular}{|c|c|c|c|c|c|c|c|}
\hline \multirow[b]{2}{*}{ Item } & \multicolumn{4}{|c|}{ Met concentration in the infusate } & \multirow[b]{2}{*}{$\mathrm{SE}$} & \multicolumn{2}{|c|}{$P$-value } \\
\hline & $100 \%$ & $60 \%$ & $30 \%$ & $0 \%$ & & Linear & Quadratic \\
\hline \multicolumn{8}{|l|}{ EAA } \\
\hline Met & 339.5 & 285.9 & 301.2 & 336.9 & 102.4 & 0.982 & 0.553 \\
\hline Lys & 1,500 & 1,555 & 1,684 & 1,482 & 548 & 0.953 & 0.777 \\
\hline Thr & 1,495 & 1,181 & 679 & 275 & 419 & 0.034 & 0.778 \\
\hline Val & 1,567 & 1,528 & 917 & 1,654 & 442 & 0.816 & 0.402 \\
\hline Ile & 828 & 1,198 & 1,007 & 1,011 & 339 & 0.461 & 0.138 \\
\hline Leu & 1,288 & 1,863 & 1,539 & 1,601 & 563 & 0.471 & 0.231 \\
\hline Phe & 729.7 & 416.2 & 446.1 & 432.8 & 222.3 & 0.278 & 0.453 \\
\hline His & 278.0 & 429.7 & 303.4 & 343.2 & 126.3 & 0.814 & 0.525 \\
\hline Arg & 605.4 & 564.3 & 445.3 & 547.3 & 173.9 & 0.584 & 0.644 \\
\hline \multicolumn{8}{|c|}{ NEAA } \\
\hline Ser & 416.5 & 153.5 & 313.3 & 375.0 & 175.7 & 0.969 & 0.329 \\
\hline Glu & 1,235 & 1,747 & 2,166 & 2,640 & 643 & 0.058 & 0.922 \\
\hline Gly & 2,110 & 2050 & 1,036 & 931 & 646 & 0.105 & 0.830 \\
\hline Ala & 2,597 & 710 & 1,009 & 859 & 885 & 0.147 & 0.280 \\
\hline Cys & 317.0 & 223.2 & 220.9 & 168.3 & 126 & 0.390 & 0.894 \\
\hline Tyr & 198.4 & 209.6 & 517.1 & 202.7 & 142.5 & 0.594 & 0.345 \\
\hline Pro & 1,562 & 566 & -993 & 1,698 & 2,157 & 0.865 & 0.422 \\
\hline
\end{tabular}


the optimal level of Met for lactating cows was $2.40 \%$ of dietary MP, which was supported by the results of Cho et al. (2007). However, decreased postruminal Met supply and decreased milk protein yield does not necessarily equate to decreased mammary uptake (Ying et al., 2013). Therefore, Met supply may exert a portion of its effects on milk protein synthesis through circulating hormone concentrations and intracellular signaling in mammary epithelial cells rather than through mass action. Though Met deficiency decreased the yields of milk and milk protein $(P<0.001$, Table 3$)$, mammary uptakes of Met, total AA, and all the measured AA except for Thr and Glu were not affected in the present study (Table 7 ). The decreases in milk protein yield induced by Met deficiency, at least for the short term, could therefore hardly be attributed to an effect of mass action. Whether mass action plays an important part in decreasing milk protein yield under the scenario of long-term Met deficiency is a topic worth further investigation. More profound variations in systemic metabolism pathways, including those in the rumen, may occur under this situation.

Supplementation of Met has been reported to promote milk fat production, and the study has been carried out to investigate the effects of Met on milk fat rather than milk protein productions (Lundquist et al., 1985). Results of a kinetic study using lactating goats revealed that absorbed Met contributed at least $4 \%$ of the phospholipid pool in the plasma and proposed that the lipogenic effect of Met in the liver was one of the mechanisms among others to stimulate milk and milk fat production (Emmanuel and Kennelly, 1984).
Consistent with previous studies, graded Met removal resulted in a trend for decreased milk fat yield in the present study $(P<0.1)$. The milk fat to protein ratio increased linearly with increased Met supply, which indicated a more prominent effect of Met removal on milk protein than on milk fat production.

\section{Circulating Concentrations and Mammary Metabolism of AA}

Circulating concentrations of an AA are determined by the balance of net appearance and use by body tissues. For an EAA, circulating concentrations generally decrease with decreased postruminal supply (Bequette et al., 2000; Paz et al., 2013; Ying et al., 2013; Lin et al., 2014). In fact, the efficacy of a ruminal protected EAA, such as Lys and Met, can be evaluated based on a standard curve relating postruminal supply to blood concentrations of that specific EAA (Whitehouse et al., 2017). Consistent with those expectations, both arterial and venous concentrations of Met decreased linearly with graded Met removal in the present study. Compared with the complete mixture, removing all the Met decreased arterial and venous Met concentrations by 36 and $23 \%$, respectively. The decrease in circulating Met concentrations seemed to be attenuated as reflected by the trend for a quadratic effect for venous concentrations. The quadratic effect on arterial Met was also close to the declared tendency level $(P=0.13)$.

Graded Met removal resulted in linear increases in mammary $\mathrm{BF}_{\text {Mam }}$ (Table 9), a phenomenon that has also been observed for graded Lys removal (Guo et al.,

Table 9. Effects of graded removal of Met from the AA mixture infused into jugular vein on mammary uptake to output ratio (U:O) of AA in lactating goats

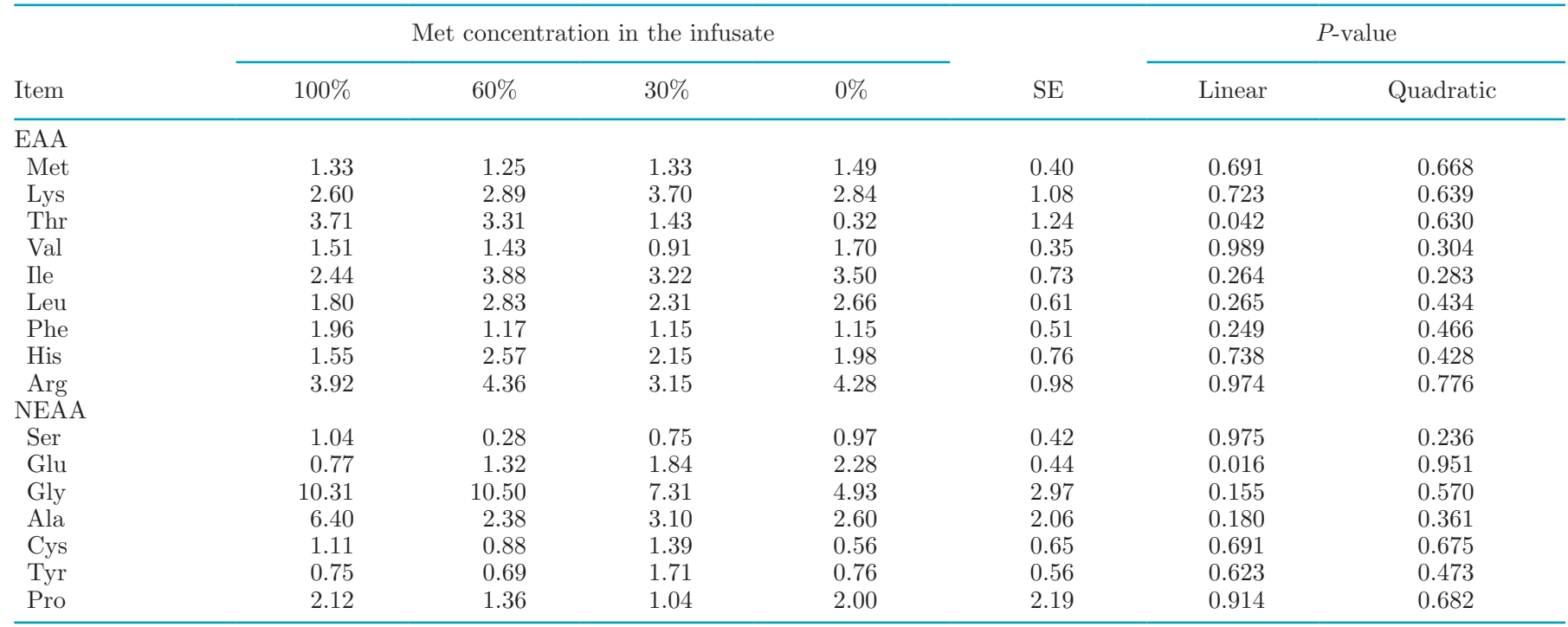


2017) and for His (Bequette et al., 2000), Leu (Bequette et al., 1996), and Arg deficiencies (Ying et al., 2013). Elevated mammary blood flow seems to therefore be a general response to individual EAA deficiency as suggested by Cant et al. (2003). Similar to Guo et al. (2017), NO concentration in the mammary vein plasma was linearly elevated by Met removal in the present study but only at the trend level of significance. If the change in NO is significant, it may at least partially explain the elevated mammary blood flow as NO has been identified as one of the local vasodilatory compounds (Laughlin and Korzick, 2001). Such a mechanism helps mitigate the effects of an AA deficiency, which helps ensure sequestration of the necessary substrates to maintain milk production.

Because blood both delivers and removes metabolites from the tissue, the overall effect on uptake depends on the resulting local tissue concentrations and the affinity of the tissue for the metabolite. Hanigan et al. (1998a) discussed the effect of variation in blood flow on tissue removal of a metabolite and pointed out that the effect depended on tissue affinity to that metabolite, which was minor if the affinity was low and was profound if it was moderate or high. Affinity of mammary tissue to individual AA was measured as $\mathrm{K}_{\text {Clearance }}$ in the present study. The combination of decreased arterial concentrations of Met, increased mammary affinity for Met, and increased mammary blood flow as Met supply decreased appeared to completely offset the negative effect of the deficiency in terms of mammary Met uptake. However, despite very similar Met uptake across the treatments, milk protein yield still declined by $30 \%$ from the complete infusion to 0 infused Met.

Although mammary affinity for Met was increased by Met deficiency in the present study, mammary affinity for Lys was not changed by varied Lys supply in a similar study (Guo et al., 2017). As far as we know, Met is an EAA that affects mTORC1 signal pathway in the mammary gland (Table 10) and is predominantly catabolized in the liver (Lapierre et al., 2005) but not Lys. Differences in effects on tissue function and metabolism among EAA may therefore contribute to their variations in supply dependence.
Graded Met removal linearly decreased mammary uptake of Thr in the present study $(P<0.05)$. In fact, Thr was the only measured EAA in which mammary uptake was significantly affected by treatments. The decrease may relate to decreased mammary affinity for Thr as $\mathrm{K}_{\text {clearance }}$ for Thr decreased linearly with graded Met removal to a near tendency level $(P=0.108)$. Mammary uptake of Thr was an issue rarely investigated in previous studies. Arterial infusion of a 5-EAA mixture (Thr, Met, Leu, Phe, and Lys) with or without insulin into lactating cows resulted in substantial variations in mammary uptakes of these AA but were statistically nonsignificant (Metcalf et al., 1991). The biggest variation was observed for $\mathrm{Thr}$, which was a $230 \%$ increase with AA and AA plus insulin infusions relative to that of the control. Removal of Met from a complete AA mixture intravenously infused into lactating goats tended to decrease mammary $\mathrm{K}_{\text {clearance }}$ for $\mathrm{Thr}$ $(P=0.075)$, but the decrease in mammary uptake of Thr was nonsignificant $(P=0.188$; Lin et al., 2014).

\section{Circulating Metabolites, Hormones, and Phosphorylation of Proteins in mTORC1 Pathway}

Graded Met removal elevated circulating urea N and glucose linearly, which indicated increased whole-body catabolism of AA and hepatic gluconeogenesis, although the reduced use of glucose for lactose synthesis might also have contributed to the elevated circulating glucose. Elevation in circulating glucose was also observed in our previous Lys removal experiment (Guo et al., 2017) but not circulating urea N. Circulating total protein was linearly decreased in the Lys removal experiment, which was not observed in the present study. For the 4 hormones measured, Met removal only decreased circulating GH to the declared tendency level. In our previous study, graded Lys removal linearly increased circulating glucagon and increased circulating insulin to a near tendency level $(P=0.153)$ but had no significant effect on circulating GH. The above results indicated differed whole-body responses to Met and Lys deficiency due to their differences in tissue func-

Table 10. Effects of graded removal of Met from the AA mixture infused into jugular vein on phosphorylation level [phosphorylation level $(\mathrm{P}) /$ total $\times 100$ ] of downstream proteins in the mechanistic target of rapamycin complex 1 signaling pathway of mammary gland tissue from lactating goats

\begin{tabular}{|c|c|c|c|c|c|c|c|}
\hline Item & \multicolumn{4}{|c|}{ Percentage of Met in complete AA mixture } & SE & \multicolumn{2}{|c|}{$P$-value } \\
\hline P-4EBP1/4EBP1 & 71.15 & 67.89 & 58.53 & 56.16 & 6.207 & 0.053 & 0.96 \\
\hline $\mathrm{P}-\mathrm{eIF} 2 / \mathrm{eIF} 2$ & 49.24 & 44.96 & 43.34 & 50.26 & 0.195 & 0.979 & 0.741 \\
\hline
\end{tabular}


tion and metabolism aside from their common roles in protein synthesis.

Amino acid availability may also regulate milk protein synthesis at the cellular level through the mTORC1 or GCN signaling pathways. Individual AA may promote milk protein synthesis by repressing the inhibitory activity of $4 \mathrm{EBP} 1$, by stimulating eIF2, and possibly by enhancing ribosomal activity through activation of ribosomal protein S6 (Arriola Apelo et al., 2014). Graded Met removal reduced phosphorylation status of $4 \mathrm{EBP} 1$ and that of p70S6k linearly, both of which would downregulate milk protein synthesis and explained the decreased milk protein yields by graded Met removal without a concomitant decrease in mammary uptakes of Met. Similar responses in the mTORC1 signaling pathway were not observed in our previous Lys experiment (Guo et al., 2017).

Given the lack of changes in uptake of EAA or hormones that might regulate milk protein synthesis, it is difficult to explain the observed changes in cell signaling and the decline in milk protein output. The data suggest that the animals were able to completely mitigate the Met shortage at the tissue level in terms of Met uptake, yet changes in cell signaling and milk protein production were consistent with a $30 \%$ change in supply and signaling. No changes occurred in measured hormone concentrations that would help to explain this dichotomy. One would certainly expect a decline in milk protein production given a significant deficiency in Met supply, but the mechanism of action remains difficult to identify.

\section{CONCLUSIONS}

Graded removal of Met from an intravenously infused AA mixture in to lactating goats linearly decreased milk protein yield. The decrease was clearly not a result of limited Met availability as mammary Met uptake was similar across treatments even when all the Met was removed from the infused AA mixture. Comparison between results of the present and our previous graded Lys removal experiment revealed that whole-body responses, including circulating urea $\mathrm{N}$, total protein, and pancreatic hormones, to deficiency of the $2 \mathrm{AA}$ were different. Intracellular mTORC1 signaling pathway was affected by short-term Met deficiency and might play a part in decreased milk protein synthesis as indicated by the varied phosphorylation status of $4 \mathrm{EBP} 1$ and p70S6k.

\section{ACKNOWLEDGMENTS}

The work is funded by National Natural Science Foundation of China (Beijing) under project number
31372340 and by China Agricultural Research System (Beijing) under the project CARS-37.

\section{REFERENCES}

AFRC. 1993. Energy and Protein Requirements of Ruminants. CAB International, Wallingford, UK.

Appuhamy, J. A., J. R. Knapp, O. Becvar, J. Escobar, and M. D. Hanigan. 2011. Effects of jugular-infused lysine, methionine, and branched-chain amino acids on milk protein synthesis in high-producing dairy cows. J. Dairy Sci. 94:1952-1960.

Appuhamy, J. A. D. R. N. 2010. Regulatory roles of essential amino acids, energy, and insulin in mammary cell protein synthesis. $\mathrm{PhD}$ Diss. Animal Sciences, Virginia Polytechnic Institute and State University, Blacksburg.

Arriola Apelo, S. I., J. R. Knapp, and M. D. Hanigan. 2014. Invited review: Current representation and future trends of predicting amino acid utilization in the lactating dairy cow. J. Dairy Sci. 97:4000-4017.

Baker, D. H. 1996. Advances in amino acid nutrition and metabolism of swine and poultry. Pages 41-52 in Nutrient Management of Food Animals to Enhance and Protect the Environment. E. T. Kornegay, ed. CRC Press, Boca Raton, FL.

Bequette, B. J., F. R. C. Backwell, J. C. MacRae, G. E. Lobley, L. A. Crompton, J. A. Metcalf, and J. D. Sutton. 1996. Effect of intravenous amino acid infusion on leucine oxidation across the mammary gland of the lactating goat. J. Dairy Sci. 79:2217-2224.

Bequette, B. J., M. D. Hanigan, A. G. Calder, C. K. Reynolds, G. E. Lobley, and J. C. MacRae. 2000. Amino acid exchange by the mammary gland of lactating goats when histidine limits milk production. J. Dairy Sci. 83:765-775.

Bequette, B. J., C. Kyle, L. Crompton, V. Buchan, and M. Hanigan. 2001. Insulin regulates milk production and mammary gland and hind-leg amino acid fluxes and blood flow in lactating goats. J. Dairy Sci. 84:241-255.

Berthiaume, R., P. Dubreuil, M. Stevenson, B. W. McBride, and H. Lapierre. 2001. Intestinal disappearance, mesenteric and portal appearance of amino acids in dairy cows fed ruminally protected methionine. J. Dairy Sci. 84:194-203.

Berthiaume, R., M. C. Thivierge, G. E. Lobley, P. Dubreuil, M. Babkine, and H. Lapierre. 2002. Effect of a jugular infusion of essential amino acids on splanchnic metabolism in dairy cows fed a protein deficient diet. J. Dairy Sci. 85(Suppl. 1):72-73. (Abstr.)

Cant, J. P., R. Berthiaume, H. Lapierre, P. H. Luimes, B. W. McBride, and D. Pacheco. 2003. Responses of the bovine mammary glands to absorptive supply of single amino acids. Can. J. Anim. Sci. 83:341-355.

Chen, Z. H., G. A. Broderick, N. D. Luchini, B. K. Sloan, and E. Devillard. 2011. Effect of feeding different sources of rumen-protected methionine on milk production and N-utilization in lactating dairy cows. J. Dairy Sci. 94:1978-1988. https://doi.org/10.3168/jds.2010 -3578 .

Cho, J., T. R. Overton, C. G. Schwab, and L. W. Tauer. 2007. Determining the amount of rumen-protected methionine supplement that corresponds to the optimal levels of methionine in metabolizable protein for maximizing milk protein production and profit on dairy farms. J. Dairy Sci. 90:4908-4916. https://doi.org/10.3168/ jds.2007-0314.

Donkin, S. S., G. A. Varga, T. F. Sweeney, and L. D. Muller. 1989. Rumen-protected methionine and lysine: Effects on animal performance, milk protein yield, and physiological measures. J. Dairy Sci. 72:1484-1491. https://doi.org/10.3168/jds.S0022-0302(89)79258 -4 .

Emmanuel, B., and J. J. Kennelly. 1984. Kinetics of methionine and choline and their incorporation into plasma lipids and milk components in lactating goats. J. Dairy Sci. 67:1912-1918. https://doi .org/10.3168/jds.S0022-0302(84)81524-6.

Guinard, J., and H. Rulquin. 1995. Effect of graded amount of duodenal infusions of methionine on the mammary uptake of major milk precursors in dairy cows. J. Dairy Sci. 78:2196-2207. 
Guo, C. L., Y. T. Li, X. Y. Lin, M. D. Hanigan, Z. G. Yan, Z. Y. Hu, Q. L. Hou, F. G. Jiang, and Z. H. Wang. 2017. Effects of graded removal of lysine from an intravenously infused amino acid mixture on lactation performance and mammary amino acid metabolism in lactating goats. J. Dairy Sci. 100:4552-4564.

Güttler, F., C. Kühl, L. Pedersen, and P. Påby. 1978. Effects of oral phenylalanine load on plasma glucagon, insulin, AA and glucose concentrations in man. Scand. J. Clin. Lab. Invest. 38:255-260.

Hanigan, M. D., J. P. Cant, D. C. Weakley, and J. L. Beckett. 1998b. An evaluation of post absorptive protein and amino acid metabolism in the lactating dairy cow. J. Dairy Sci. 81:3385-3401.

Hanigan, M. D., C. Reynolds, D. Humphries, B. Lupoli, and J. Sutton. 2004. A model of net amino acid absorption and utilization by the portal-drained viscera of the lactating dairy cow. J. Dairy Sci. 87:4247-4268.

Hanigan, M. D., J. France, L. A. Crompton, and B. J. Bequette. 2000. Evaluation of a representation of the limiting amino acid theory for milk protein synthesis. Pages 127-144 in Modelling Nutrient Utilization in Farm Animals. J. P. McNamara, J. France, and D. E. Beever, ed. CABI, Wallingford, UK.

Hanigan, M. D., J. France, D. Wray-Cahen, D. E. Beever, G. E. Lobley, L. Reutzel, and N. E. Smith. 1998a. Alternative models for analyses of liver and mammary transorgan metabolite extraction data. Br. J. Nutr. 79:63-78.

Hristov, A. N., W. J. Price, and B. Shafii. 2004. A meta-analysis examining the relationship among dietary factors, dry matter intake, and milk and milk protein yield in dairy cows. J. Dairy Sci. $87: 2184-2196$.

Kim, S. G., G. R. Buel, and J. Blenis. 2013. Nutrient regulation of the mTOR complex 1 signaling pathway. Mol. Cells 35:463-473.

Lapierre, H., R. Berthiaume, G. Raggio, M. C. Thivierge, L. Doepel, D. Pacheco, P. Dubreuil, and G. E. Lobley. 2005. The route of absorbed nitrogen into milk protein. Anim. Sci. 80:11-22.

Lapierre, H., G. E. Lobley, D. R. Ouellet, L. Doepel, and D. Pacheco. 2007. Amino acid requirements for lactating dairy cows: Reconciling predictive models and biology. Pages 39-59 in Proc. Cornell Nutrition Conference for Feed Manufacturers. Department of Animal Science, Cornell University, Ithaca, NY.

Laughlin, M. H., and D. H. Korzick. 2001. Vascular smooth muscle: Integrator of vasoactive signals during exercise hyperemia. Med. Sci. Sports Exerc. 33:81-91.

Lee, C., A. N. Hristov, T. W. Cassidy, K. S. Heyler, H. Lapierre, G. A. Varga, M. J. de Veth, R. A. Patton, and C. Parys. 2012. Rumenprotected lysine, methionine, and histidine increase milk protein yield in dairy cows fed a metabolizable protein-deficient diet. J. Dairy Sci. 95:6042-6056. https://doi.org/10.3168/jds.2012-5581.

Lin, X. Y., J. F. Wang, P. C. Su, Y. Wang, and Z. H. Wang. 2014 Lactation responses and mammary amino acid metabolism in lactating goats when complete or Met lacking amino acid mixtures were infused into the jugular vein. Small Rumin. Res. 120:135-141.

Liu, G. M., M. D. Hanigan, X. Y. Lin, K. Zhao, F. G. Jiang, R. R. White, Y. Wang, Z. Y. Hu, and Z. H. Wang. 2017. Methionine, leucine, isoleucine, or threonine effects on mammary cell signaling and pup growth in lactating mice. J. Dairy Sci. 100:4038-4050.

Lundquist, R. G., D. E. Otterby, and J. G. Linn. 1985. Influence of three concentrations of DL-methionine or methionine hydroxy analog on milk yield and milk composition. J. Dairy Sci. 68:3350 3354. https://doi.org/10.3168/jds.S0022-0302(85)81245-5.

Mackle, T. R., D. A. Dwyer, K. L. Ingvartsen, P. Y. Chouinard, D. A. Ross, and D. E. Bauman. 2000. Effects of insulin and postruminal supply of protein on use of amino acids by the mammary gland for milk protein synthesis. J. Dairy Sci. 83:93-105.

Metcalf, J. A., J. D. Sutton, J. E. Cockburn, D. J. Napper, and D. E. Beever. 1991. The influence of insulin and amino acid supply on amino acid uptake by the lactating bovine mammary gland. J. Dairy Sci. 74:3412-3420.

Misciattelli, L., V. F. Kristensen, M. Vestergaard, M. R. Weisbjerg, K. Sejrsen, and T. Hvelplund. 2003. Milk production, nutrient utilization, and endocrine responses to increased postruminal lysine and methionine supply in dairy cows. J. Dairy Sci. 86:275-286. https:/ /doi.org/10.3168/jds.S0022-0302(03)73606-6.

Nahm, K. H. 2002. Efficient feed nutrient utilization to reduce pollutants in poultry and swine manure. Crit. Rev. Environ. Sci. Technol. 32:1-16.

Noftsger, S., and N. R. St-Pierre. 2003. Supplementation of methionine and selection of highly digestible rumen undegradable protein to improve nitrogen efficiency for milk production. J. Dairy Sci. 86:958-969. https://doi.org/10.3168/jds.S0022-0302(03)73679-0.

NRC. 2001. Nutrient Requirements of Dairy Cattle. 7th rev. ed. Natl. Acad. Press, Washington, DC.

Paz, H. A., M. J. de Veth, R. S. Ordway, and P. J. Kononoff. 2013. Evaluation of rumen-protected lysine supplementation to lactating dairy cows consuming increasing amounts of distillers dried grains with solubles. J. Dairy Sci. 96:7210-7222.

Rogers, J. A., U. Krishnamoorthy, and C. J. Sniffen. 1987. Plasma amino acids and milk protein production by cows fed rumen-protected methionine and lysine. J. Dairy Sci. 70:789-798. https://doi .org/10.3168/jds.S0022-0302(87)80075-9.

Stone, K. P., D. Wanders, M. Orgeron, C. C. Cortez, and T. W. Gettys. 2014. Mechanisms of increased in vivo insulin sensitivity by dietary methionine restriction in mice. Diabetes 63:3721-3733.

Whitehouse, N. L., C. G. Schwab, and A. F. Brito. 2017. The plasma free amino acid dose-response technique: A proposed methodology for determining lysine relative bioavailability of rumen-protected lysine supplements. J. Dairy Sci. 100:9585-9601. https://doi.org/ 10.3168/jds.S0022-0302(83)82054-2.

Wray-Cahen, D., J. Metcalf, F. Backwell, B. Bequette, D. Brown, J. Sutton, and G. Lobley. 1997. Hepatic response to increased exogenous supply of plasma amino acids by infusion into the mesenteric vein of Holstein-Friesian cows in late gestation. Br. J. Nutr. 78:913-930.

Ying, F., X. Y. Lin, W. M. Ma, H. L. Chi, Z. G. Yan, Y. F. Song, and Z. H. Wang. 2013. Metabolic responses to the deficiency of Lys, Arg, Met, or His in the mammary gland of lactating goats. Small Rumin. Res. 113:219-230.

Zhou, Z., M. Vailati-Riboni, E. Trevisi, J. K. Drackley, D. N. Luchini, and J. J. Loor. 2016. Better postpartal performance in dairy cows supplemented with rumen-protected methionine compared with choline during the peripartal period. J. Dairy Sci. 99:1-17. https:/ /doi.org/10.3168/jds.S0022-0302(83)82054-2. 